từ cấp II trở xuống. Sự khác biệt có ý nghĩa thống kê $(\mathrm{OR}=2,226$; $\mathrm{CI}: 1,395-3,552, \mathrm{P}=0,001)$.

\section{BÀN LUÂ̂N}

Ở nghiên cứu này chúng tôi thấy rằng không có mối liên quan giữa tuổi, nghề nghiệp, và nơi sống với kiến thức chăm sóc của bà mẹ với các chỉ số lần lượt là $(\mathrm{OR}=1,455 ; \mathrm{CI}: 0,717-2,954$; $\mathrm{P}=0,299)$, (OR=1,012; CI: 0,784-1,308; $\mathrm{P}=0,925)$, (OR=0,364; CI: 0,106- 1,246; $\mathrm{P}=0,107)$.

Kết quả từ bảng 5 cho thãy trình độ học vấn của bà mẹ có liên quan đến kiến thức chăm sóc sau sinh của bà mẹ. Về trình độ học vấn các bà me có trình độ học vấn từ trung cấp/ cao đẳng, đại học có cớ hội đạt kiến thức chăm sóc sau sinh gấp 2,2 lần các bà mẹ có trình độ học vấn từ cấp II trở xuống. Sự khác biệt có ý nghĩa thống kê $(\mathrm{OR}=2,226 ; \quad \mathrm{CI}: 1,395$ - 3,552; $\mathrm{P}=0,001)$. Khác với nghiên cứu của Phạm Phương Lan năm 2011 [6].

Mặc dù không có mối tương đồng với nghiên cứu trước đây, kết quả của nghiên cứu này cũng lý giải là có thể là trình độ học vấn càng cao thì các bà mẹ càng có nhiều kiến thức chăm sóc sức khỏe cho bản than và cho trẻ sơ sinh của họ, và hộ cũng có nhiều cơ hội để nhận được các kiến thức hơn so với những bà mẹ có trình độ học vấn thấp hơn.

\section{KẾT LUÂN}

Không có mối liên quan giữa tuổi, nghề nghiệp, và nơi sống với kiến thức chăm sóc của bà mẹ với các chỉ số lần lượt là $(\mathrm{OR}=1,455$; $\mathrm{CI}$ : $0,717-2,954 ; \mathrm{P}=0,299)$ ，(OR=1,012; CI: 0,784$1,308 ; P=0,925)$, $(O R=0,364 ; C I: 0,106-1,246$; $\mathrm{P}=0,107)$.

Về trình độ học vấn các bà me có trình độ học vấn từ trung cấp/ cao đẳng, đại học có cơ hội đạt kiến thức chăm sóc sau sinh gấp 2,2 lần các bà me có trình độ học vấn từ cấp II trở xuống. Sự khác biệt có ý nghĩa thống kê (OR=2,226; CI: 1,395-3,552; $\mathrm{P}=0,001)$.

\section{TÀI LIÊU THAM KHẢO}

1. Ngố Văn Toàn (2007), "Hiểu biết về các dấu hiệu nguy hiểm trước, trong và sau khi sinh của các cắp vơ chồng tại 7 tỉnh năm 2006". Tạp chí Y học thực hành, số $9(577+578)$, tr.25-28

2. Võ Văn Thắng (2007), "Thực trạng chăm sóc dịch vụ thai sản và KHHGĐ" Giáo trình quản lý sức kh̉o sinh sản, tr 40-45

3. Phạm Phương Lan, (2014), " Thực trạng chăm sóc sau sinh của bà me ở hai bênh viên trên đia bàn Hà nội và đánh giá mô hình chăm sóc sau sinh tại nhà"

4. Lane, D. A., Kauls, L.S., Ickovics, J. R., Naftolin, F., and Feinstein, A. R. (1999). "Early postpartum discharges. Impact on distress and outpatient problems". Archives of Family Medicine. 8, 237-242.

5. Bệnh viện Phụ sản Thái Bình (2016), " Báo cáo tổng kết 12 tháng năm 2015"

\title{
ĐÁNH GIÁ TÁC DỰG PHỤ CỦA TẾ BÀO CAR-T TRÊN ĐộNG VẬT THỰC NGHIỆM
}

\section{Đặng Thành Chung1, Ngô Thu Hằng1, Bùi Khắc Cường 1 , Cấn Văn Mão}

\section{TÓM TẮT}

Mục tiêu: Đánh giá tác dụng phụ của tế bào CART trên động vật thực nghiệm. Đối tượng và phương pháp: Chuột nhắt trắng được tiêm đường phúc mạc liều duy nhất $5 \times 10^{5}, 10^{6}$ và $5 \times 10^{6}$ tế bào CAR- T/chuột ở nhóm nghiên cứu và $10^{6}$ tế bào PBMC/chuôt ở nhóm chứng. Sau tiêm, theo dõi tình trạng toàn thân, đánh giá chức phận tạo máu, ảnh hưởng chức năng gan, thận và sự thay đổi nồng độ các cytokine IL2, IL6, TNF-a trong huyết thanh chuột bằng kỹ thuật ELISA.

\footnotetext{
${ }^{1}$ Hoc viên quân y

Chịu trách nhiệm chính: Cấn Văn Mão

Email: canvanmao2011@gmail.com

Ngày nhận bài: 8.01.2021

Ngày phản biên khoa hoc: 9.3.2021

Ngày duyệt bài: 16.3.2021
}

Kết quả: Trọng lượng chuột, các xét nghiệm đánh giá chức phận tạo máu, ảnh hưởng chức năng gan, thận và nồng độ các cytokine IL2, IL6, TNF-a trong huyết thanh chuột ở cả 3 nhóm tiêm CAR-T với liều khác $(p>0,05)$. Kết luận: Tế bào CAR-T không gây tác dụng phụ trên đông vật thực nghiệm sau 4 tuần theo dõi.

Tư khóa: CAR-T, tác dụng phụ, cytokine

\section{SUMMARY}

\section{EVALUATING THE SIDE EFFECTS OF CAR-T} CELLS ON EXPERIMENTAL ANIMALS

Objectives: This study aims to evaluate of side effects of CAR-T cells on experimental animals. Methods: Mice are injected a single doses of $5 \times 10^{5}$ $10^{6}$ and $5 \times 10^{6}$ CAR-T cell in the study group and $10^{6}$ PBMC cell into the peritoneal cavity. Animals were weighed and given health assessments every day. nhau không có sự khác biệt có ý nghĩa so với lô chứng 
Evaluating the hematopoietic function, liver function, kidney function and change the concentration of cytokines IL2, IL6, TNF-a in mouse serum by ELISA technique. Results: Weight, hematopoietic function, liver function, kidney function and concentrations of cytokines IL2, IL6, and TNF-a in all 3 groups injected CAR-T at doses differences had no significant difference compared to the control group ( $p>0.05$ ). Conclusion: CAR-T did not cause side effects in experimental animals 4 weeks after treatment.

Keywords: CAR-T cell, side effects, cytokines

\section{I. Đă̆T VẤN ĐỀ}

Bệnh bạch cầu nguyên bào lympho cấp tính (ALL, Bệnh bạch cầu cấp dòng lympho, Lơ xê mi cấp dòng lympho) là một trong những bệnh ung thư phổ biến nhất ở trẻ em trên thế giới, chiếm khoảng $75 \%$ tất cả các loại ung thư máu [1]. ALL xuất hiện khi quá trình tạo tế bào máu trong tủy xương bị biến đổi, tạo ra các tế bào bạch cầu bất thường, ác tính. Theo thống kê trên thế giới, tỷ lệ mắc ALL hàng năm khoảng 1 đến 4 $\mathrm{ca} / 100.000$ dân tùy vào vùng địa lý trong đó tỷ lệ mắc mới của ALL gặp nhiều nhất ở lứa tuổi từ 2-5 tuổi [2]. Điều trị bênh ALL là nhằm tiêu diêt các tế bào bạch cầu ác tính và phục hồi tuỷ xương trở lại bình thường. Liệu pháp điều trị chủ yếu hiện được sử dụng cho ALL là hóa trị liệu, thường chia thành 3 giai đoạn: cảm ứng, củng cố và duy trì. Hạn chế của các liệu pháp hóa trị liệu là hầu như không có khả năng chữa khỏi bệnh hoàn toàn mà chỉ hướng đến thuyên giảm toàn phần để có thể được điều trị tiếp bằng liệu pháp ghép tế bào gốc đồng loài. Tuy nhiên, tỷ lệ thuyên giảm toàn phần theo đường hướng điều trị này cũng không cao, chỉ đạt tối đa $20 \%$ ở người trưởng thành [3]. Liệu pháp miễn dịch sử dụng tế bào $T$ mang thụ thể nhân tạo $\mathrm{CAR}$ (Chimeric antigen receptors) là một hướng tiếp cận mới. Nguyên tắc của liệu pháp CAR-T trong điều trị ung thư là nhằm tạo ra các tế bào $\mathrm{T}$ mang các thụ thể nhân tạo có khả năng nhận biết các kháng nguyên đặc hiệu trên bề mặt tế bào ung thư từ đó kích hoạt khả năng phân giải tế bào ung thư của tế bào T. Năm 2017, cơ quan thực phẩm và dược phẩm hoa kỳ (FDA) đã cấp phép cho 2 dạng điêu trị sử dụng CAR-T là Kymriah của hãng Novartis cho điều trị bệnh bạch cầu lympho cấp ở trẻ em và Yescarta của hãng Kite Pharma cho các bệnh lymphoma không phải Hodgkin ở người lớn.

Tuy nhiên, ở Việt Nam chưa ứng dụng liệu pháp tế bào CAR-T để điều trị ung thư nói chung và $A L L$ nói riêng. Do đó, chúng tôi tiến hành nghiên cứu ứng dụng liệu pháp tế bào CAR-T trong điều trị bạch cầu nguyên bào lympho cấp.

\section{II. ĐỐI TƯỢNG VÀ PHƯƠNG PHÁP NGHIÊN CỨU}

\section{1. Đối tượng, vật liệu nghiên cứu}

2.1.1. Đối tượng nghiên cứu

- Chuột nhắt, lông trắng, cân nặng $25 \mathrm{~g} \pm 5 \mathrm{~g}$, do Trung tâm động vật Học viện Quân y cung cấp đủ tiêu chuẩn thí nghiệm. Số lượng 24 con.

- Tế bào CAR-T (sản phẩm của đề tài $\mathrm{KC}$ $10.39 / 16-20$ ) với liều lượng: $5 \times 10^{5} ; 10^{6}$ và $5 \times 10^{6}$ tế bào/chuột.

- Tế bào PBMC nồng độ $10^{6}$ làm nhóm chứng.

\subsubsection{Nguyên vật liệu nghiên cứu}

- Môi trường nuôi cấy tế bào ung thư RPMI RPMI-1640, huyết thanh bào thai bò (FBS = fetal bovin serum) $10 \%$; dung dịch penicillin và streptomycin 1\%; trypsin-EDTA (Invitrogen $\mathrm{GmbH}$, Karlsruhe, Cộng hòa Liên bang Đức).

- Bộ kít ELISA định lượng IL1, IL6 được cung cấp bởi Thermo Fisher Scientific

- Kít định lượng các enzym và chất chuyển hóa trong máu: Urea/bun-color, Creatinine, Aspartate minotransferase (AST/GOT), Alanine Aminotransferase (ALT/GPT), của Hãng Biosystems/ Tây Ban Nha.

- Dung dịch xét nghiệm máu hóa chất Swelab, Hãng Swelab, Thụy Điển

- Các hóa chất xét nghiệm và làm tiêu bản mô bệnh học

- Máy Sinh hóa bán tự động BTS 350, hãng Biosystem, Tây Ban Nha, Sản xuất năm 2014.

- Máy phân tích huyết học Swelab Alpha, Hãng Swelab, Thụy Điển, Sản xuất năm 2014

- Cân phân tích của Nhật.

- Các vất tư tiêu hao cần thiết phục vụ cho nuôi cấy tế bào: Chai nuôi cấy tế bào, pipet, chai đựng môi trường, lọc vi khuẩn 0,45 ㅆm (ATCC, Hoa Kỳ).

- Hế thống phòng thí nghiệm phục vụ nuôi cấy tế bào: Phòng sach, tủ ấm $\mathrm{CO} 2$, kính hiển vi soi ngược, máy ly tâm, tủ mát $4^{\circ} \mathrm{C}$, tủ âm $-20^{\circ} \mathrm{C}$, $-80^{\circ} \mathrm{C}$, bình chứa Nitớ lỏng.

\subsection{Phương pháp nghiên cứu}

Nghiên cứu được thiết kế là nghiên cứu thực nghiệm, mô tả cắt ngang có đối chứng.

Chuột nhắt trắng chiếu xạ liều $1 \mathrm{~Gy}$ làm giảm miễn dịch 2 ngày trước khi tiêm tế bào CAR-T. Số lượng 24 chuột được chia thành 4 lô, mỗi lô 6 con, tiêm liều duy nhất, đường phúc mạc.

- Nhóm 1 (chứng sinh học) $(n=6)$ : Tế bào $\mathrm{PBMC}$ nồng độ $10^{6} \mathrm{~TB} / \mathrm{chuột}$

Nhóm CAR-T $1(n=6)$ : Tế bào CAR-T nồng độ $5 \times 10^{5} \mathrm{~TB} / \mathrm{chuột}$

- Nhóm CAR-T $2(n=6)$ : Tế bào CAR-T nồng độ $10^{6}$ TB/chuột 
- Nhóm CAR-T $3(n=6)$ : Tế bào CAR-T nồng độ $5 \times 10^{6}$ TB/chuột

Các chỉ tiêu theo dõi trước và trong quá trình nghiên cứu:

- Tình trạng chung, thể trọng của chuột

- Đánh giá chức phận tạo máu thông qua số lượng hồng cầu, hàm lượng hemoglobin, số lượng bạch cầu, công thức bạch cầu.

- Đánh giá mức độ hủy hoại tế bào gan thông qua định lượng hoạt độ enzym trong máu: ALT, AST.

- Đánh giá chức năng thận thông qua định lượng nồng độ ure, creatinin huyết thanh.

- Đánh giá sự thay đổi nồng độ các cytokin (IL2, IL6, TNF-a) trong huyết thanh chuột ở các nhóm bằng kỹ thuật ELISA.

- Mô bệnh học: sau 4 tuần tiêm, chuột được mổ để quan sát đại thể toàn bộ các cơ quan. Kiểm tra ngẫu nhiên cấu trúc vi thể gan, thận của $50 \%$ số chuột ở mỗi lô. Các xét nghiệm vi thể được thực hiện tại Bộ môn Giải phẫu bệnh, Bệnh viện 103.

Các thông số được kiểm tra ở các thời điểm 4 tuần tiêm thuốc.

2.3. Xử lý thống kê: So sánh trung bình của 2 nhóm độc lập bằng T-test, so sánh trung bình của 3 nhóm bằng phân tích phương sai ANOVA. Số liệu được xử lý bằng phần mềm SPSS 20.0 và GraphPad Prism 6. Sự khác biệt có ý nghĩa thống kê khi $p<0,05$.

\section{KẾT QUẢ NGHIÊN CỨU}

3.1. Tình trạng toàn thân, sự thay đổi trọng lượng chuột trong quá trình thí nghiệm. Sau khi ghép tế bào CAR-T và PBMC, chuột vẫn ăn uống, hoạt động bình thường, nhanh nhẹn, lông mượt, mắt trong, hậu môn khô, không thấy biểu hiện đi lỏng. Sau 4 tuần thí nghiệm, tỷ lệ chuột sống ở 4 nhóm chuột là 100\%.

Bảng 1. Ảnh hưởng của tếbào CAR-T lên trọng lượng cơ thể chuột nghiên cứu (g)

\begin{tabular}{|c|c|c|c|c|c|}
\hline Nhóm Ngày & N0 & N7 & N14 & N21 & N28 \\
\hline Nhóm chứng (1) & $21,82 \pm 3,15$ & $24,42 \pm 2,10$ & $26,50 \pm 2,13$ & $29,12 \pm 4,20$ & $31,26 \pm 2,52$ \\
\hline Nhóm CAR-T 1 (2) & $22,57 \pm 1,16$ & $26,62 \pm 2,43$ & $28,05 \pm 1,68$ & $28,73 \pm 2,66$ & $31,78 \pm 2,69$ \\
\hline Nhóm CAR-T 2 (3) & $22,98 \pm 0,98$ & $27,55 \pm 3,33$ & $30,90 \pm 2,66$ & $32,38 \pm 4,25$ & $34,46 \pm 3,41$ \\
\hline Nhóm CAR-T 3 (4) & $22,49 \pm 2,16$ & $25,62 \pm 3,75$ & $27,13 \pm 5,60$ & $30,74 \pm 5,74$ & $33,72 \pm 5,70$ \\
\hline$P_{21}$ & $>0,05$ & $>0,05$ & $>0,05$ & $>0,05$ & $>0,05$ \\
\hline$P_{31}$ & $>0,05$ & $>0,05$ & $>0,05$ & $>0,05$ & $>0,05$ \\
\hline$P_{41}$ & $>0,05$ & $>0,05$ & $>0,05$ & $>0,05$ & $>0,05$ \\
\hline
\end{tabular}

Sau tiêm tế bào CAR-T (nhóm điều tri) và PBMC (nhóm chứng), theo dõi 4 tuần thấy trong lương chuột ở các nhóm đều tăng so với trước khi nghiên cứu (Bảng 1). Trọng lượng chuột ở các nhóm điêu trị tương tự như ở nhóm chứng, sự khác biệt không có ý nghĩa thống kê ( $p>0,05)$.

3.2. Đánh giá ảnh hưởng của tế bào CAR-T đến chức năng tạo máu

Bảng 2. Ánh hưởng của tế bào CAR-T đến số lượng hồng cẩu, tiểu cầu, bạch cầu trong máu chuột nghiên cứu

\begin{tabular}{|c|c|c|c|c|}
\hline Chỉ tiêu & Nhóm chứng (1) & $\begin{array}{c}\text { Nhóm } \\
\text { CAR-T } 1 \text { (2) }\end{array}$ & $\begin{array}{c}\text { Nhóm } \\
\text { CAR-T } 2 \text { (3) }\end{array}$ & $\begin{array}{c}\text { Nhóm } \\
\text { CAR-T } 3 \text { (4) }\end{array}$ \\
\hline Số lượng hồng câu (T/L) & $8,16 \pm 0,83$ & $8,07 \pm 1,07$ & $8,04 \pm 1,44$ & $9,00 \pm 0,55$ \\
\hline Hemoglobin $(\mathrm{g} / \mathrm{L})$ & $107,60 \pm 13,58$ & $107,80 \pm 15,67$ & $104,80 \pm 22,14$ & $120,80 \pm 9,15$ \\
\hline HCT (\%) & $37,64 \pm 4,40$ & $37,06 \pm 6,82$ & $37,00 \pm 6,24$ & $41,34 \pm 4,78$ \\
\hline Số lượng tiếu cầu(G/L) & $767,00 \pm 80,68$ & $855,00 \pm 304,32$ & $778,20 \pm 62,70$ & $940,60 \pm 227,45$ \\
\hline Số lượng bạch câu(G/l) & $6,90 \pm 3,88$ & $4,91 \pm 1,64$ & $5,84 \pm 0,73$ & $7,96 \pm 2,71$ \\
\hline $\begin{array}{l}\text { Số lượng bạch cầu } \\
\text { trung tính }(\mathrm{G} / \mathrm{l})\end{array}$ & $1,07 \pm 0,71$ & $0,64 \pm 0,27$ & $0,81 \pm 0,36$ & $0,65 \pm 0,25$ \\
\hline $\begin{array}{l}\text { Tỷ lệ bạch cầu } \\
\text { trung tính (\%) }\end{array}$ & $15,62 \pm 4,32$ & $12,92 \pm 2,73$ & $13,54 \pm 4,25$ & $8,52 \pm 2,83$ \\
\hline $\begin{array}{l}\text { Số lượng bạch cầu } \\
\text { lympho }(\mathrm{G} / \mathrm{I})\end{array}$ & $4,31 \pm 2,16$ & $2,89 \pm 1,02$ & $3,83 \pm 0,47$ & $6,17 \pm 2,46$ \\
\hline $\begin{array}{l}\text { Tý lệ bạch cầu } \\
\text { lympho (\%) }\end{array}$ & $63,40 \pm 6,88$ & $60,36 \pm 13,32$ & $13,32 \pm 7,66$ & $76,48 \pm 6,90$ \\
\hline$P_{21}, P_{31}, P_{41}$ & & & & \\
\hline
\end{tabular}

Kết quả ở các bảng 2 cho thấy: sau 4 tuần tiêm tế bào CAR-T vào phúc mạc chuột, các xét 
nghiệm đánh giá chức năng tạo máu (số lượng hồng cầu, Hemoglobin, HCT, số lượng tiểu cầu, số lượng bạch cầu, số lượng bạch câu trung tính, số lượng bạch cầu lympho, công thức bạch cầu ở cả 3

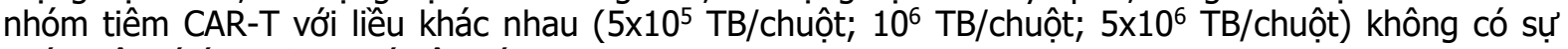
khác biệt có ý nghĩa so với lô chứng ( $p>0,05)$.

3.3. Đánh giá mức độ hủy hoại tế bào gan

Bảng 3. Ánh hưởng của tế bào CAR-T đến hoạt độ AST, ALT trong máu chuột

\begin{tabular}{|c|c|c|c|c|}
\hline Chỉ số & $\begin{array}{l}\text { Nhóm chứng } \\
\text { (1) }\end{array}$ & $\begin{array}{c}\text { Nhóm } \\
\text { CAR-T 1 (2) }\end{array}$ & $\begin{array}{c}\text { Nhóm } \\
\text { CAR-T } 2 \text { (3) }\end{array}$ & $\begin{array}{l}\text { Nhóm } \\
\text { CAR-T } 3 \text { (4) }\end{array}$ \\
\hline Hoạt độ AST (UI/L) & $47,73 \pm 6,20$ & $46,52 \pm 3,50$ & $45,48 \pm 4,67$ & $47,04 \pm 3,58$ \\
\hline Hoạt độ ALT (UI/L) & $54,45 \pm 7,52$ & $54,05 \pm 9,12$ & $54,56 \pm 9,35$ & $52,36 \pm 9,79$ \\
\hline $\mathbf{P}_{21}, \mathbf{P}_{31}, \mathbf{P}_{41}$ & & & & \\
\hline
\end{tabular}

Sau 4 tuần tiêm tế bào CAR-T, các xét nghiệm đánh giá mức độ hủy hoại tế bào gan (hoạt độ

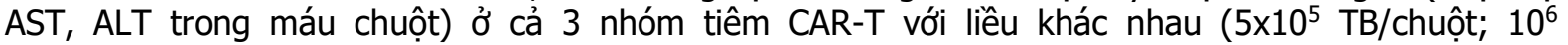
TB/chuột; $\left.5 \times 10^{6} \mathrm{~TB} / \mathrm{chuột}\right)$ đều không có sự khác biệt có ý nghĩa so với lô chứng $(p>0,05)$.

3.4. Đánh giá chức năng thận. Nồng độ Ure và Creatinin trong máu chuột ở cả 3 nhóm tiêm CAR-T với liều khác nhau ( $5 \times 10^{5} \mathrm{~TB} /$ chuột; $10^{6} \mathrm{~TB} /$ chuột; $\left.5 \times 10^{6} \mathrm{~TB} / \mathrm{chuột}\right)$ đều không có sự khác biệt có ý nghĩa so với lô chứng ( $p>0,05)$ (Bảng 4).

Bảng 4. Ánh hưởng của tế bào CAR-T đến nồng độ ure và creatinin trong máu chuột

\begin{tabular}{|c|c|c|c|c|}
\hline Chỉ tiêu & $\begin{array}{c}\text { Nhóm chứng } \\
(\mathbf{1})\end{array}$ & $\begin{array}{c}\text { Nhóm } \\
\text { CAR-T 1 (2) }\end{array}$ & $\begin{array}{c}\text { Nhóm } \\
\text { CAR-T 2 (3) }\end{array}$ & $\begin{array}{c}\text { Nhóm } \\
\text { CAR-T 3 (4) }\end{array}$ \\
\hline Ure $(\mathrm{mmol} / \mathrm{L})$ & $5,95 \pm 1,13$ & $5,77 \pm 1,34$ & $6,06 \pm 0,96$ & $6,48 \pm 1,18$ \\
\hline Creatinin $(\mu \mathrm{mol} / \mathrm{L})$ & $66,03 \pm 4,75$ & $63,98 \pm 9,53$ & $64,36 \pm 6,23$ & $66,14 \pm 12,17$ \\
\hline $\mathbf{P}_{\mathbf{2 1}}, \mathbf{p}_{\mathbf{3 1}} \mathbf{p} \mathbf{p}_{\mathbf{4 1}}$ & & \multicolumn{3}{|c|}{$>0,05$} \\
\hline
\end{tabular}

\subsection{Thay đổi về mô bệnh học gan, thận sau 4 tuần tiêm tế bào CAR-T}

Hình thái vi thể gan ở nhóm chứng và các nhóm tiêm CAR-T không có sự khác biệt: Nhu mô gan bình thường, tĩnh mạch cửa bị sung huyết nhe (mũi tên xanh) các xoang mạch không giãn. (Hình 1).

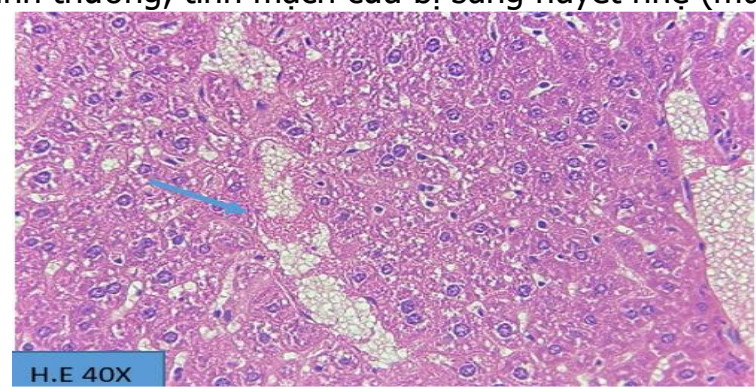

Nhóm chứng

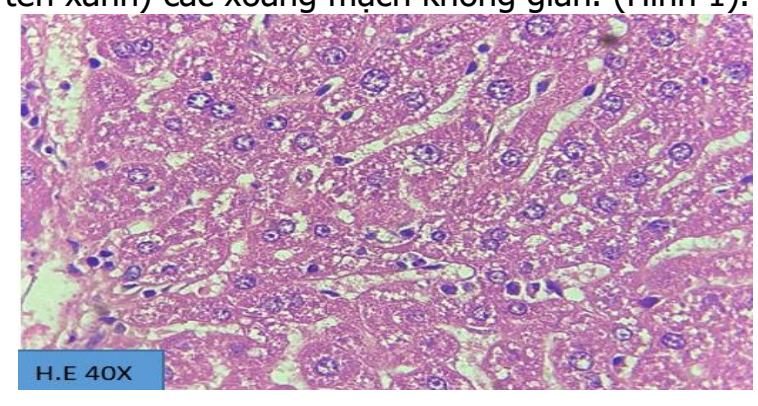

Nhóm tiêm CAR-T

Hình 1: Hình thái vi thể gan chuột ở nhóm chứng và nhóm tiêm tê bào CAR-T

Hình thái vi thể thận ở nhóm chứng và các nhóm tiêm CAR-T không có sự khác biệt: cấu trúc các cầu thận khá đồng dạng, có tăng sinh nhẹ chất nền gian mạch (mũi tên xanh). Các tế bào biểu mô ống thận không bị thoái hóa. Các mao mạch không bị sung huyết. (hình 2)

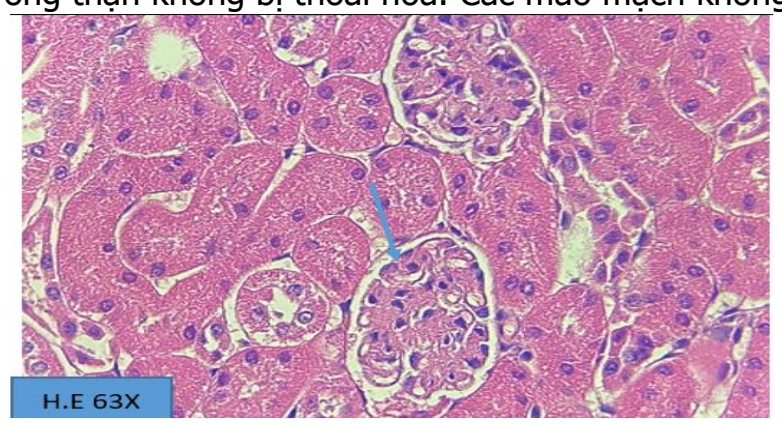

Nhóm chứng

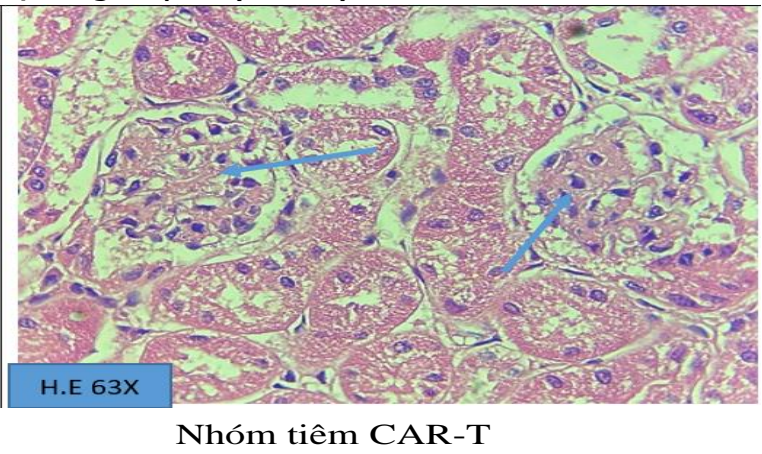

Nhóm tiêm CAR-T

Hình 2: Hình thái vi thể thận chuột ở nhóm chứng và nhóm tiêm tế bào CAR-T 


\begin{tabular}{|c|c|c|c|c|c|}
\hline \multicolumn{2}{|c|}{ Cytokine } & Nhóm chứng (1) & $\begin{array}{c}\text { Nhóm } \\
\text { CAR-T } 1 \text { (2) }\end{array}$ & $\begin{array}{c}\text { Nhóm } \\
\text { CAR-T } 2 \text { (3) }\end{array}$ & $\begin{array}{c}\text { Nhóm } \\
\text { CAR-T } 3 \text { (4) }\end{array}$ \\
\hline \multirow[b]{2}{*}{$\begin{array}{c}\mathrm{IL}-2 \\
(\mathrm{pg} / \mathrm{mL})\end{array}$} & $(\bar{X} \pm S D)$ & $18,347 \pm 2,722$ & $22,843 \pm 7,742$ & $24,929 \pm 10,490$ & $21,905 \pm 4,924$ \\
\hline & $\begin{array}{l}\text { Trung vị } \\
\text { (TPV25- } \\
\text { TPV75) } \\
\end{array}$ & $\begin{array}{c}17,130 \\
(17,130-17,130)\end{array}$ & $\begin{array}{c}26,024 \\
(17,130- \\
28,830) \\
\end{array}$ & $\begin{array}{c}26,024 \\
(23,217- \\
33,997) \\
\end{array}$ & $\begin{array}{c}23,217 \\
(17,130-23,217)\end{array}$ \\
\hline \multirow[b]{2}{*}{$\begin{array}{c}\mathrm{IL}-6 \\
(\mathrm{pg} / \mathrm{mL})\end{array}$} & $(\bar{X} \pm S D)$ & $\begin{array}{c}135,131 \\
\pm 81,693 \\
\end{array}$ & $\begin{array}{c}134,429 \\
\pm 151,747 \\
\end{array}$ & $\begin{array}{c}177,046 \\
\pm 153,889 \\
\end{array}$ & $\begin{array}{c}270,502 \\
\pm 443,720 \\
\end{array}$ \\
\hline & $\begin{array}{l}\text { Trung vị } \\
\text { (TPV25- } \\
\text { TPV75) }\end{array}$ & $\begin{array}{c}17,130 \\
(10,218-39,164)\end{array}$ & $\begin{array}{l}173,433 \\
(98,673- \\
178,089)\end{array}$ & $\begin{array}{c}54,651 \\
(36,283- \\
217,650)\end{array}$ & $\begin{array}{c}104,551 \\
(55,291- \\
193,148)\end{array}$ \\
\hline \multirow[b]{2}{*}{$\begin{array}{l}\text { TNF-a } \\
(\mathrm{pg} / \mathrm{mL})\end{array}$} & $(\bar{X} \pm S D)$ & $168,415 \pm 69,169$ & $\begin{array}{c}360,115 \pm \\
345,355\end{array}$ & $\begin{array}{c}170,361 \pm \\
14,606\end{array}$ & $\begin{array}{c}224,854 \pm \\
61,350\end{array}$ \\
\hline & $\begin{array}{l}\text { Trung vị } \\
\text { (TPV25- } \\
\text { TPV75) }\end{array}$ & $\begin{array}{c}117,448 \\
(10,140-166,449)\end{array}$ & $\begin{array}{c}117,427 \\
(86,882- \\
145,480)\end{array}$ & $\begin{array}{c}129,857 \\
(129,857- \\
163,058)\end{array}$ & $\begin{array}{c}243,724 \\
(163,058- \\
289,446)\end{array}$ \\
\hline \multicolumn{2}{|c|}{$P_{21}, p_{31}, p_{41}$} & \multicolumn{4}{|c|}{$>0,05$} \\
\hline
\end{tabular}

Nồng đô các cytokine IL-2, IL-6 và TNF-a trong máu chuột sau 4 tuần ở cả 3 nhóm tiêm CAR-T

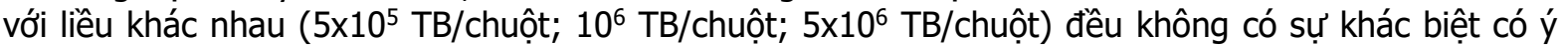
nghĩa so với lô chứng $(p>0,05)$.

\section{BÀN LUÂN}

Mặc dù liệu pháp tế bào CAR-T đã chứng minh được tính khả thi trong lâm sàng, đôi khi liệu pháp này cũng gây nhiều độc tính có thể đe doạ tính mạng, như hội chứng giải phóng cytokine hay bão cytokine, gây độc thần kinh, tấn công nhầm đích và hội chứng suy hô hấp cấp. Trong điều trị ALL bằng liệu pháp tế bào CAR-T, những vấn đề an toàn cần lưu ý là hiện tượng "on-target, off-tumor", hội chứng giải phóng cytokine và nguy cơ phát sinh các đột biến gây ung thư do sự chèn cấu trúc di truyền vào thể gen của tế bào $T$. Một số phương pháp đã được sử dụng nhằm giảm các tác dụng phụ của liệu pháp tế bào CAR-T như: chuyển đồng thời 2 cấu trúc $C A R$ vào tế bào $T$, nhằm nhân biết 2 kháng nguyên khác nhau trên tế bào ung thư [4], cảm ứng biểu hiện CAR thông qua thụ thể NOTCH nhân tạo, sử dụng chiến lược gen tự sát (suicide gene) trong thiết kế tế bào CAR-T nhằm kiểm soát sự tăng sinh của tế bào CAR-T trong cơ thể người bệnh, hạn chế hiện tượng "on-target, off-tumor" hay phát sinh các tế bào $T$ ung thu' [5].

Nghiên cứu của chúng tôi cho thấy tế bào CAR-T với 3 nồng độ nhau ( $5 \times 10^{5}$ TB/chuột; $10^{6}$ TB/chuột; $5 \times 10^{6} \mathrm{~TB} /$ chuột) không gây tác dụng phụ trên động vật thực nghiệm sau 4 tuần theo dõi. Tất cả các chỉ số theo dõi về tình trạng chung, cân nặng, chức năng tạo máu, chức năng gan, mức độ hủy hoại tế bào gan, chức năng thận, nồng độ các cytokine và mô bệnh học gan, thận đều nằm trong giới hạn bình thường, không có sự khác biệt rõ rệt so với nhóm chứng. Kết quả này chứng tỏ hiệu quả của việc tối ưu hóa các cấu trúc CAR, quy trình chuyển gen của nhóm nghiên cứu để giảm thiểu tối đa tác dụng phụ của liệu pháp CAR - T trong điều trị.

\section{KẾT LUẬN}

Nghiên cứu của chúng tôi cho thấy tế bào CAR-T không gây tác dụng phụ trên động vật thực nghiệm.

\section{TÀI LIẸU THAM KHẢO}

1. Jemal, A., et al., Cancer statistics, 2010. CA Cancer J Clin, 2010. 60(5): p. 277-300.

2. Stanulla, M. and $\mathbf{M}$. Schrappe, Treatment of childhood acute lymphoblastic leukemia. Semin Hematol, 2009. 46(1): p. 52-63.

3. Terwilliger, T. and $M$. Abdul-Hay, Acute lymphoblastic leukemia: a comprehensive review and 2017 update. Blood Cancer J, 2017. 7(6): p. e577.

4. Kloss, C.C., et al., Combinatorial antigen recognition with balanced signaling promotes selective tumor eradication by engineered $\mathrm{T}$ cells. Nat Biotechnol, 2013. 31(1): p. 71-5.

5. Labanieh, L., R.G. Majzner, and C.L. Mackall, Programming CAR-T cells to kill cancer. Nat Biomed Eng, 2018. 2(6): p. 377-391. 